\title{
Foreword
}

\section{Entrepreneurship in Meiji Japan}

I

$\mathrm{N}$ THE KNOWLEDGE-BASED computer software industry in the United States, entrepreneurial activities in which risky and innovative projects are undertaken in order to produce new products-or new ways of producing existing products-can be found in abundance, and such activities have been the driving force behind economic development in that country. In Japan, on the other hand, the economy has experienced a recession that has lasted for more than ten years, ever since the collapse of the bubble economy in the early 1990s, and getting out of that recession has become a matter of great concern. One measure that is being looked at as an effective remedy is deregulation, which would encourage the growth of entrepreneurial behavior. The need for deregulation in the financial and higher education sectors in particular has already been signalled. ${ }^{1}$ As one part of such deregulation, plans are being made for national universities here in Japan to be reorganized into independent administrative legal bodies-or agencies-and this is expected to have major effects on research and education in the universities.

Thus it is that in recent years, especially in Japan, there has been a growth of interest in entrepreneurship. The subject has been drawing the attention of business history scholars as well, so much so that the Forum for Entrepreneurial Studies was established in Osaka last year (2002) in a tie-up with the Osaka Chamber of Commerce. Also, there has been a steady stream of publications dealing

${ }^{1}$ See, for example, George G. Daly, "Entrepreneurship and Business Culture in Japan and the U.S." Japan and the World Economy 10/4 (1998).

${ }^{2}$ Hiroyuki Itami et al., eds., Kèsubukku Nihon kigyō no keiei kōdō 2: Kigyōka seishin to senryaku [A casebook of managerial behavior in Japanese enterprise 2: Entrepreneurial 
with entrepreneurs. ${ }^{2}$ It is for these reasons that I decided that the topic to be featured in this issue of the Yearbook would be entrepreneurship. And the reasons I decided to focus especially on the Meiji Period, which was the time when this country's modern economy was formed, are twofold: one, that the character of an entrepreneur depends on the age (for example, in the early stage of economic growth, Japanese entrepreneurs endeavored to import Western technologies and institutions, though today's entrepreneurs produce 'original' products on the basis of their own research and development activities), and two, that the use of new sources has meant that we are now getting a different picture of the three entrepreneurs who are taken up for study in this issue.

For those who are not familiar with the subject, the first to make a detailed study of entrepreneurship was Joseph A. Schumpeter. ${ }^{3}$ Schumpeter defined enterprise as "the carrying out of new combinations" such as the introduction of a new manufactured product and the introduction of a new production method; those people who carried out such new combinations he called "entrepreneurs." Maintaining that something like the introduction of an epoch-making new production method that upsets an already existing economic equilibrium cannot be explained merely by market factors,

spirit and strategy] (Tokyo: Yūhikaku, 1998); Hiroyuki Itami et al., eds., A Casebook of Managerial Behavior in Japanese Enterprise 4: Entrepreneurs and the Breath of an Age (Tokyo: Yūhikaku, 1998); Matao Miyamoto, Kigyōkatachi no chōsen [The challenge taken up by entrepreneurs] (Tokyo: Chūōkōron Shinsha, 1999); Masaru Udagawa et al., eds., Késubukku Nihon no kigyōka katsudō [A casebook of entrepreneurial activities in Japan] (Tokyo: Yūhikaku, 1999); Satoshi Sasaki, ed., Nihon no kigyōka gunzō [Images of Japan's entrepreneurs] (Tokyo: Maruzen, 2000); Satoshi Sasaki, ed., Nihon no sengo kigyöka shi: Hankotsu no keifu [A history of Japan's postwar entrepreneurs: A genealogy of rebelliousness] (Toko: Yūhikaku, 2001); Masaru Udagawa et al., eds., Kêsu sutad̄̄: Nihon no kigyōka shi [A history of entrepreneurs in Japan: Case studies] (Tokyo: Bunshindō, 2002); Michael J. Lynskey and Seiichiro Yonekura, eds., Entrepreneurship and Organization: The Role of the Entrepreneur in Organizational Innovation (Oxford: Oxford Univesity Press, 2002).

${ }^{3}$ For much of the discussion that follows I am heavily indebted to the following two works: James H. Soltow, "The Entrepreneur in Economic History," American Economic Review 58/2 (1968); Sidney M. Greenfield and Arnold Strickon, "A New Paradigm for the Study of Entrepreneurship and Social Change," Economic Development and Cultural Change 29/3 (1981).

${ }^{4}$ Joseph A. Schumpeter, The Theory of Economic Development, 4th ed. (New Brunswick and London: Transaction Publishers, 1996), pp. 66, 74. 
Schumpeter looked for an answer in a noneconomic factor: the individual. As I see it, he was positing a situation in which the future of some new technology was uncertain and yet some individual braves the risk and introduces a new method of production, and that is why he believed that radical innovation occurred only once in a few decades and always as a result of "technology push."

There can be no disputing the fact that it was Arthur H. Cole and the other scholars who assembled at Harvard's Research Center in Entrepreneurial History who developed entrepreneurship from the point of view of economic history and business history. Their aim was to synthesize the subject not only from an economic or historical perspective but also from a diversity of academic fields such as sociology and psychology. Learning more about the social backgrounds from which entrepreneurs sprung, and more about the things that motivated them, had been recognized as an important matter for those interested in developing the economies of developing countries. To allow more room for such analyses to move ahead, Cole extended Schumpeter's narrow definition of an entrepreneur. This symbolically appears in the fact that Cole deliberately does not include employment of innovation, "at least innovation in the usual sense" (meaning as understood by Schumpeter, I guess), in his definition of entrepreneurial activities. ${ }^{5}$

Such an extension of entrepreneurial activities was necessary, it would seem, from the large amount of research on case studies that had been accumulated; to the innovation instigated by entrepreneurs was added incremental innovation, and the idea of entrepreneurs was widened from that of founders and presidents to include also people from lower strata in companies. Scholars became aware of another aspect of the introduction of new technology: "demand pull," or the introduction of a new production method as a result of awareness of market needs. ${ }^{6}$ In view of the fact that Schumpeter also took part in that Research Center in Entrepreneurial History at Harvard, it is rather surprising that this new understanding of innovation was critical also of Schumpeter's view that an entrepreneur

${ }^{5}$ Arthur H. Cole, Business Enterprise in Its Social Setting (Cambridge: Harvard University Press, 1959), p. 14.

${ }^{6}$ Obviously, as long as the market does not accept a technology, it will not spread, so it is a mistake to think of demand pull and technology push as simple dichotomies. 
acted as an exogenous force that shifted the economy from a given state of equilibrium; rather, the new view had much in common with the views of Israel M. Kirzner, who held that the entrepreneur acted to lead the economy to equilibrium. ${ }^{7}$ It should be noted that it was revealed that large numbers of entrepreneurs who had contributed to economic development had been people from minority groups in many countries, and that this revelation would have a large impact on research on the spirit of Japanese entrepreneurs.

Research in Japan on the spirit of Japanese entrepreneurs (and here I am talking about Meiji Period entrepreneurs only) is closely linked with research on the development of Japan's economy. In the 1960s, when Japan was the only country in Asia to achieve modern economic growth, it was generally believed that this had to be due in large part to noneconomic factors, and the role of government in supporting the growth was considered an important factor. When attention also turned to the entrepreneurs, people started stressing the role played by the warrior class, who did not act only for their private interests but rather for national interests, and when the origins of early-Meiji entrepreneurs were investigated, it was found that large numbers were from the warrior class. This way of thinking ran like a common thread through the studies of Japanese and non-Japanese researchers alike, beginning with Takao Tsuchiya, Gustav Ranis, and Johannes Hirschmeier; it had an affinity with the aforementioned discovery about the role of minority groups. ${ }^{8}$

It was Kozo Yamamura who first cast some doubt on this accepted wisdom. ${ }^{9}$ He showed that, in the waning years of the Tokugawa era

${ }^{7}$ Israel M. Kirzner, Competition and Entrepreneurship (Chicago and London: University of Chicago Press, 1973), pp. 73-74.

${ }^{8}$ Takao Tsuchiya, Nihon shihon shugi no keieishiteki kenky $\bar{u}$ [Business historical studies of Japanese capitalism] (Tokyo: Misuzu Shobō, 1954); Gustav Ranis, "The CommunityCentered Entrepreneur in Japanese Development," Explorations in Entrepreneurial History 7 (1950); Johannes Hirschmeier, The Origins of Entrepreneurship in Meiji Japan (Cambridge: Harvard University Press, 1964).

${ }^{9}$ Kozo Yamamura, "A Re-Examination of Entrepreneurship in Meiji Japan (1869-1912)," Economic History Review 21/1 (1968); Henry Rosovsky and Kozo Yamamura, "Entrepreneurial Studies in Japan: An Introduction," Business History Review 44/1 (1970); Kozo Yamamura, "Entrepreneurship, Ownership, and Management in Japan," in The Economic Emergence of Modern Japan, ed. Kozo Yamamura (Cambridge: Cambridge University Press, 1997) (first published in The Cambridge Economic History of Europe, Part II, 1978). 
that preceded the Meiji Period, the borderline between warrior class and merchant class was blurred; that quite a large number of entrepreneurs who were counted among the warrior class were warrior class in name only; and, taking up the case of Zenjirō Yasuda, a typical banker, that the behavior of entrepreneurs can be explained as driven by personal gain. According to Hiroshi Mannari, the proportion of former samurai among business leaders was far higher than the proportion of the warrior class among the total population, though it was lower among political leaders and intellectual leaders. ${ }^{10}$ The reason of business leaders' low figures, as Hirschmeier has also pointed out, is that most of the entrepreneurs in the traditional industries were from the ranks of the commoners (i.e., peasants, artisans, and merchants). ${ }^{11}$ In the newly introduced industries from the West, in which higher education was necessary for leaders, the role of ex-samurai people was very important. Ex-samurai elite led people in many fields because they received higher education. In this way, we should be cautious to conclude that ex-samurai people were active in business because they had nationalistic point of view. There has not been any major dispute in regard to entrepreneurs in the years since Yamamura's works appeared, but Matao Miyamoto, the present chairman of the Business History Society of Japan, in the work cited above in note 2 chides those who stress the role of the government in economic development for attributing too much to the government, and his way of thinking is similar to that of Yamamura. He stresses that, in a period of change, the role of a Schumpeter-type entrepreneur is important, and he is not in favor of reducing the motivation of entrepreneurs to personal gain. ${ }^{12}$

The feature articles in this issue also follow along this line of research on Japan's entrepreneurs, in that they consider the role of the entrepreneur in starting up a new business in a period of change important. The article by Shimada shows that Eiichi Shibu-

${ }^{10}$ Hiroshi Mannari, The Japanese Business Leaders (Tokyo: University of Tokyo Press, 1974).

${ }^{11}$ Johannes Hirschmeier, "Shibusawa Eiichi: Industrial Pioneer," in The State and Economic Enterprise in Japan: Essays in the Political Economy of Growth, ed. William W. Lockwood (Princeton: Princeton University Press, 1965).

${ }_{12}$ M. Miyamoto, The Challenge Taken Up by Entrepreneurs, pp. 1-24. 
sawa, who has mostly been depicted as a public figure hardly distinguishable from a government bureaucrat, not only used joint-stock companies but also a variety of company formats (limited partnerships, unlimited partnerships, and dormant partnerships) to control and operate his own assets. The article by Suzuki takes up a study of Takashi Masuda, a person little known by non-Japanese researchers in comparison with Hikojirō Nakamigawa, even though for many years he held the position of manager of Mitsui, the largest zaibatsu in Japan. It shows how he moved into risky ventures with a fearless resoluteness backed up by meticulous care, to lead to successful outcomes not only the largest trading company that existed in Japan-Mitsui Bussan-but also the two manufacturing companies Taiwan Sugar Refining Co. and Shanghai Cotton Spinning Co. The article also makes clear once again the importance of being able to maintain amicable relations with owner families in a zaibatsu if one is to succeed in managing their assets. The third article, by Saitō, analyzes the activities of Sōichirō Asano, who went from being penniless to being the founder of a zaibatsu. It shows us his insatiable passion for expanding business operations; his consequent perpetual problems with insufficient funds and the crucial importance of his financial links with Zenjirō Yasuda the banker; and how he was forced to get rid of a part of his business empire and restructure it during the recessions between the two world wars.

I fervently hope that these three feature articles will act as a stimulus to further research on the subject of entrepreneurship.

Makoto Kasuya, Editor The University of Tokyo 